\title{
ESTIMATIONS OF CHOLESTEROL, TRIGLYCERIDES AND FRACTIONATION OF LIPOPROTEINS IN SERUM SAMPLES OF SOME NIGERIAN FEMALE SUBJECTS
}

\author{
E.I. Adeyeye ${ }^{1 *}$ and I. Oluwadare ${ }^{2}$ \\ ${ }^{1}$ Department of Chemistry, University of Ado Ekiti, P.M.B. 5363, Ado Ekiti, Nigeria \\ ${ }^{2}$ Department of Science Laboratory Technology, Moshood Abiola Polytechnic, P.M.B. 2210, \\ Ojere, Abeokuta, Nigeria
}

(Received December 14, 2009; revised August 26, 2010)

\begin{abstract}
Blood samples (serum) were collected to determine some biochemical parameters: total glycerides (TG), total cholesterol (TC), high density lipoprotein-cholesterol (HDL-C), low density lipoprotein-cholesterol (LDL-C) and very low density lipoprotein-cholesterol (VLDL-C) in 53 female subjects in Warri, Delta State, Nigeria using the Reflotron ${ }^{\circledR}$ (an auto analyser), supported with the use of questionnaire to get information on age and sex. Age range of the subjects was $18-80$ years. The TG levels in all the subjects were $<200 \mathrm{mg} / \mathrm{dL}$; only one subject $(1.89 \%)$ had TC $<200 \mathrm{mg} / \mathrm{dL}$; nine subjects $(17.0 \%)$ had HDL-C $\leq 35 \mathrm{mg} / \mathrm{dL}$; for LDL-C only one subject $(1.89 \%)$ had a desirable level of $<130 \mathrm{mg} / \mathrm{dL}$; for VLDL-C 29 subjects $(54.7 \%)$ had values $17.2 \mathrm{mg} / \mathrm{dL}$ and above. For therapeutic decision-making, TC/HDL-C and LDL-C/HDL-C, were calculated. In TC/HDL-C, three subjects $(5.66 \%)$ had values $<4.4$ and in LDL-C/HDL-C, 41 subjects $(77.4 \%)$ had values $<4.5$. Hence, TC, HDL-C, LDL-C, TC/HDL-C and slightly LDL-C/HDL-C and VLDL-C in the subjects could lead to increase coronary heart diseases. Results were matched for the age and sex of subjects.
\end{abstract}

KEY WORDS: Female serum, Biochemical studies, Therapeutic decision-making

\section{INTRODUCTION}

Blood is the fluid filling the heart and blood vessels. It consists of a colourless fluid, plasma, in which are suspended the red blood corpuscles, the white corpuscles and the platelets [1]. It has been found that non-communicable diseases such as depression and heart diseases are fast replacing infectious diseases and malnutrition as the leading causes of disability and premature death [2].

Cholesterol is a crystalline substance of a fatty nature found in the brain, nerves, blood and bile. It may crystallize in the gallbladder and along arterial wall [1]. High cholesterol level in diets is linked to increased risk of heart disease $(>200 \mathrm{mg} / \mathrm{dL})$ and other fat related diseases such as obesity, certain types of cancer, e.g. cancer of the colon, gallbladder and breast [3]. Total cholesterol in the body had been categorized as follows: $<200 \mathrm{mg} / \mathrm{dL}$ (desirable), 200-239 $\mathrm{mg} / \mathrm{dL}$ (borderline high) and $\geq 240 \mathrm{mg} / \mathrm{dL}$ (high) or $5.17 \mathrm{mmol} / \mathrm{L}, 5.17-6.18 \mathrm{mmol} / \mathrm{L}$ and 6.21 $\mathrm{mmol} / \mathrm{L}$, respectively [4]. High density lipoprotein-cholesterol (HDL-C) is a plasma protein cholesterol complex that is relatively high in protein and low in cholesterol. Its major function is in transportation of cholesterol and other lipids from tissues to liver [1]. HDL-C is often referred to as "good cholesterol" because it removes cholesterol from the peripheral tissues and returns it to liver for possible degradation [5]. HDL includes $20 \%$ as cholesterol. HDL-C in the body had been categorized as follows: $\leq 35 \mathrm{mg} / \mathrm{dL}$ (indicates risk) although this is being debated to be too low for women, it is $0.91 \mathrm{mmol} / \mathrm{L}$; LDL-to-HDL ratio: men: $>5.0$ (indicates risk), women: $>4.5$ (indicates risk) [4]. Low density lipoprotein-cholesterol (LDL-C) contains high proportion of cholesterol (46\% of molecule is cholesterol). It transports cholesterol from the liver to other body cells, hence often referred to as "bad cholesterol" since it can be taken up by muscle cells in arteries and have been implicated in the development of arteriosclerosis (hardening of the arteries that leads to coronary heart diseases, stroke and other diseases) [6]. Triglycerides are esters of glycerol with three fatty acids and $95 \%$ of the lipids found in foods

*Corresponding author. E-mail: eiadeyeye@yahoo.com 
are triglycerides. Total triglycerides (fasting) in the body had been categorized as follows: $<200$ $\mathrm{mg} / \mathrm{dL}$ (desirable), 200-400 mg/dL (borderline high) 400-1000 mg/dL (high) and $>1000 \mathrm{mg} / \mathrm{dL}$ (very high) or $5.17 \mathrm{mmol} / \mathrm{L}, 5.17-10.34 \mathrm{mmol} / \mathrm{L}, 10.34-25.86 \mathrm{mmol} / \mathrm{L}$ and $>25.86 \mathrm{mmol} / \mathrm{L}$, respectively [4]. High triglycerides alone normally do not indicate direct risk, but may reflect lipoprotein abnormalities associated with coronary heart disease (CHD). The risk of CHD increases as triglyceride levels increase in people with other risk factors. High triglycerides also occur in conditions such as kidney disease and diabetes, which suggest a high CHD risk [7]. Endogenously liver cells form and release very low density lipoprotein (VLDL) into the circulation (i.e. reassembly of lipids from the diet which have been transported to the liver). Exogenously, VLDL is also formed from lipids in the diet and released by the intestinal mucosal cells following absorption of fat from the diet. VLDL circulating half-life is about 2-4 $\mathrm{h}$ [8]. VLDL contains $8 \%$ cholesterol.

In this report, concentrations of the following biochemical parameters in the serum were investigated: TC, HDL-C, LDL-C, VLDL-C, and TG. Also reported were the age ranges in groups of the subjects (females). This type of work will assist us to know the levels of susceptibility of those subjects to cardiovascular diseases and other blood related diseases and how to minimize or eliminate them.

\section{EXPERIMENTAL}

\section{Questionnaire/collection of samples}

Subjects involved in this type of study were those who came into the hospital for normal blood test. The technologist collected the blood sample into a clean bottle of $30 \mu \mathrm{L}$ in microvette tubes (EDTA) and used within two minutes of collection. Questionnaire forms were normally given to the subjects to complete and the information contained among others were: name, age, sex, etc. Samples were colleted from a hospital based in Warri, Delta State, Nigeria (Nigerian National Petroleum Corporation).

\section{Determination of $T C, H D L-C$, and $T G$}

Reflotron ${ }^{\circledR}$ system was used for these analyses. Reflotron ${ }^{\circledR}$ plus is a compact reflectance photometer for fully automatic evaluation of Reflotron ${ }^{\circledR}$ tests. The instrument takes charge of all functions such as heating, automatic calibration, test execution and evaluation and calculation of results. Reflotron ${ }^{\circledR}$ tests are reagent strips for specific testing of important clinical-chemistry parameters directly from whole blood, plasma or serum. The direct use of whole blood is made possible through an integrated plasma separation pad. Reflotron ${ }^{\circledR}$ plus (model Reflotron ${ }^{\circledR}$ plus) is a product of Bio-Stat Diagnostic Systems, Pepper Road, Hazel Grove, Strockport, Cheshire SK7 5BW (USA). The instrument has information on test principle and wavelength for each test and measuring ranges. Fasting blood samples were used.

Most testing methods for LDL-C do not actually measure LDL-C in their blood, much less particle size. For cost reasons, LDL-C values have long been estimated using the Friedewald formula (or a variant) [9]: [total cholesterol]-[total HDL] $-20 \%$ of the triglycerides values = estimated LDL-C. Or: LDL-C = [Total cholesterol - (HDL-C+Triglycerides/5)] [10]. This formula cannot be used, however, if blood triglycerides are $>400 \mathrm{mg} / \mathrm{dL}$ [10]. The basis of this formula is that TC is defined as the sum of HDL, LDL and VLDL. Ordinarily just the TC, HDL and TG are actually measured. The VLDL is estimated as one-fifth of the triglycerides. This formula was used to estimate LDL and VLDL in the samples. The term LDL-C (and HDL-C, VLDL-C) is used when expressing the blood concentration since it is the cholesterol content of these lipoproteins that is actually measured. The reference standard for expressing blood lipid concentrations also generally refers to the serum concentration. This is what remains after blood 
clots, and is then centrifuged to remove all red and white blood cells and clotting factors. Although blood cholesterol is a common term, the value actually refers to the concentration in the serum portion of the blood [10]. Hence, these determinations were actually in the serum.

\section{Statistical analysis}

For the purpose of therapeutic decision-making, the followings were calculated: LDL-C/HDL-C and TC/HDL-C ratios for the subjects. Also calculated were the variance ratio $-5 \%$ point for distribution of $\mathrm{F}$ within subjects of the same age group and the same parameter of TC/HDL-C, LDL-C/HDL-C, TC, TG, LDL-C, HDL-C and VLDL-C to find if differences were significant [11]. Also calculated were the grand mean, standard deviation and coefficient of variation.

\section{RESULTS AND DISCUSSION}

Table 1 shows the total cholesterol (TC), high density lipoprotein-cholesterol (HDL-C), low density lipoprotein-cholesterol (LDL-C), very low density lipoprotein-cholesterol (VLDL-C) and total glyceride (TG) for age group of 11-20 years. Ten subjects were in this group. The TC range was $200-244 \mathrm{mg} / \mathrm{dL}$ with a mean of $228 \pm 16 \mathrm{mg} / \mathrm{dL}$ and a coefficient of variation percent $(\mathrm{CV})$ of $7 \%$. The HDL-C showed a variation of $27.8-80.1 \mathrm{mg} / \mathrm{dL}$ with a mean of $50.1 \pm 16.2$ $\mathrm{mg} / \mathrm{dL}$ and higher CV of $32 \%$. The LDL-C range was $140-171 \mathrm{mg} / \mathrm{dL}$, mean of $161 \pm 10 \mathrm{mg} / \mathrm{dL}$ and CV of $6 \%$ which was less than the CV \% of HDL-C. The VLDL range was 15.1-20.0 $\mathrm{mg} / \mathrm{dL}$, mean of $17.3 \pm 1.58 \mathrm{mg} / \mathrm{dL}$ and $\mathrm{CV} \%$ of 9.09 . The TG range was $58.6-100.1 \mathrm{mg} / \mathrm{dL}$ with a mean of $86.69 \pm 7.88 \mathrm{mg} / \mathrm{dL}$ and CV of $9 \%$ which was similar to the CV \% of VLDL-C. Table 2 depicts the TC/HDL-C and LDL-C/HDL-C ratios. The range of values was 3.0-7.19 with a mean of $4.94 \pm 1.39$ and $\mathrm{CV}$ of $28 \%$ for TC/HDL-C whilst the LDL-C/HDL-C had a range of 1.75-5.61 with a mean of 3.56 \pm 1.25 and $\mathrm{CV}$ of $35 \%$. In Table 3 parameter values of subjects of age group 21-30 years are shown. For TC, the range was $197-314 \mathrm{mg} / \mathrm{dL}$ with a mean of $224 \pm 23$ $\mathrm{mg} / \mathrm{dL}$ and CV of $10 \%$. HDL-C range was $28.5-90 \mathrm{mg} / \mathrm{dL}$ and a mean of $45.9 \pm 14.4 \mathrm{mg} / \mathrm{dL}$ and a slightly higher CV of $31 \%$. The LDL-C had a range value of $125-202 \mathrm{mg} / \mathrm{dL}$ and a mean of $161 \pm 14 \mathrm{mg} / \mathrm{dL}$ with CV of $9 \%$. VLDL-C had a range value of $10.8-19.3 \mathrm{mg} / \mathrm{dL}$ and a mean of $17.4 \pm 2.15 \mathrm{mg} / \mathrm{dL}$ and $\mathrm{CV}$ of $12 \%$. TG showed a range of $54-111 \mathrm{mg} / \mathrm{dL}$, mean of $86.8 \pm 10.7$ $\mathrm{mg} / \mathrm{dL}$ and $\mathrm{CV}$ of $12 \%$. Table 4 shows the ratios of TC/HDL-C and LDL-C/HDL-C and LDLC/HDL-C. The range of values in TC/HDL-C was 2.93-7.05, mean of 5.19 \pm 1.07 and CV of $21 \%$. LDL-C/HDL-C ranged between $1.68-5.40$, mean of $3.78 \pm 0.97$ and CV of $26 \%$. Table 5 shows the values of the TC, HDL-C, LDL-C, VLDL-C and TG in the serum of age group 31-40 years. The TC range was $202-256 \mathrm{mg} / \mathrm{dL}$ with a mean of $226 \pm 28 \mathrm{mg} / \mathrm{dL}$ and low $\mathrm{CV}$ of $12 \%$. HDL-C had a range of 23.4-68.4 mg/dL with a mean of $44 \pm 19 \mathrm{mg} / \mathrm{dL}$ and relatively higher CV of $44 \%$. The range in LDL-C was $147-178 \mathrm{mg} / \mathrm{dL}$ and a mean of $164 \pm 13 \mathrm{mg} / \mathrm{dL}$ and a lower CV\% of 8. The VLDL-C had a range of $16.2-19.4 \mathrm{mg} / \mathrm{dL}$ with a mean of $18.0 \pm 1.4 \mathrm{mg} / \mathrm{dL}$ and a $\mathrm{CV}$ of $8.6 \%$. The TG had a range of $81.1-97.1 \mathrm{mg} / \mathrm{dL}$ with a mean of $90.1 \pm 6.89$ and low $\mathrm{CV}$ of $7.7 \%$. Both TC/HDL-C and LDL-C/HDL-C for age group 31-40 years are shown in Table 6. TC/HDL-C had a range of 3.74-8.68, mean of $5.78 \pm 2.10$ and CV of $36 \%$. Range of LDLC/HDL-C was 2.48-6.88, mean of $4.29 \pm 1.86$ and CV of $43 \%$. Table 7 contains the TC, HDL-C, LDL-C, VLDL-C and TG of age groups 41-50 (one subject), 51-60 (one subject) and 71-80 (one subject) whilst Table 8 contains their TC/HDL-C and LDL-C/HDL-C. Tables 9(a) and 9(b) show the summary of TC, HDL-C, LDL-C, VLDL-C and TG range variation in age groups 1120, 21-30 and 31-40 and their corresponding TC/HDL-C and LDL-C/HDL-C. The results of the F- test distribution calculations are used for discussion in relevant Tables; critical value was at $\alpha$ $=0.05$. 
Table 1. Lipids (mg/dL) in some Nigerian female serum samples (11-20 years age group), total number (n) $=10$.

\begin{tabular}{|l|l|l|l|l|l|l|}
\hline Statistics & Age $(\mathrm{yrs})$ & TC & HDL-C & LDL-C & VLDL-C & TG \\
\hline \multirow{5}{*}{} & 18 & 223 & 38.8 & 166 & 18.1 & 90.3 \\
\cline { 2 - 7 } & 18 & 200 & 27.8 & 153 & 19.4 & 96.9 \\
\cline { 2 - 7 } & 18 & 240 & 80.1 & 140 & 20.0 & 100 \\
\cline { 2 - 7 } & 19 & 235 & 55.7 & 163 & 16.8 & 84.0 \\
\cline { 2 - 7 } & 19 & 253 & 66.4 & 171 & 15.5 & 77.4 \\
\cline { 2 - 7 } & 20 & 244 & 58.5 & 168 & 18.0 & 90.1 \\
\cline { 2 - 7 } & 20 & 218 & 30.4 & 171 & 17.1 & 85.7 \\
\cline { 2 - 7 } & 20 & 213 & 42.4 & 154 & 17.1 & 85.5 \\
\cline { 2 - 7 } & 20 & 226 & 46.4 & 165 & 15.1 & 75.4 \\
\cline { 2 - 7 } & 20 & 231 & 54.6 & 160 & 16.3 & 81.5 \\
\hline Mean & 19 & 228 & 50.1 & 161 & 17.3 & 86.7 \\
\hline SD & 0.92 & 16 & 16 & 9.7 & 1.6 & 7.9 \\
\hline CV\% & 4.8 & 6.9 & 32 & 6.0 & 9.1 & 9.1 \\
\hline
\end{tabular}

$\mathrm{TC}=$ total cholesterol; HDL-C = high density lipoprotein cholesterol; VLDL-C = very low density lipoprotein cholesterol; LDL-C = low density lipoprotein cholesterol; TG = total triglyceride; $\mathrm{SD}=$ standard deviation; $\mathrm{CV} \%$ $=$ coefficient of variation percent. ${ }^{*}$ Results significantly different among themselves at $\alpha=0.05$.

The subjects in this report were normally people who attended hospitals for their blood tests. However, a questionnaire was always available for the subjects to complete before their blood tests could take place (for the purpose of this exercise). From such answers, their ages and sexes were obtained. The age range group was 11-80 years although no subject was in the age range of 61-70 years. The results were matched for age and sex.

The TC, HDL-C, LDL-C, VLDL-C and TG levels in the age group 11-20 years showed the CV \% of TC (7), LDL-C (6), VLDL-C (9) and TG (9) to be low or the values were very close unlike in HDL-C (32) showing its values were more scattered than the CV \% of the other four parameters (Table 1). No TC was lower than $200 \mathrm{mg} / \mathrm{dL}$; seven or 7/10 (70\%) was in borderline high of $200-239 \mathrm{mg} / \mathrm{dL}$ and three or $3 / 10$ (30\%) subjects were in the high risk of $\geq 240 \mathrm{mg} / \mathrm{dL}$. These values were higher than the value repotted $(178 \pm 43.0 \mathrm{mg} / 100 \mathrm{~mL})$ by Sowunmi et al . [12] but almost within the range (70-250 $\mathrm{mg} / \mathrm{dL})$ reported by Edozien [13]. Akinkugbe [14] reported $176 \mathrm{mg} / \mathrm{dL}$ for hypertensive and $158 \mathrm{mg} / \mathrm{dL}$ for non-hypertensive female subject of 18 years old. The HDL-C showed that two subjects or $2 / 10(20 \%)$ had HDL-C level of $\leq 35 \mathrm{mg} / \mathrm{dL}$ which is an indication of risk; eight subjects or $8 / 10$ (80\%) had HDL-C level > $35 \mathrm{mg} / \mathrm{dL}$. The level of $35 \mathrm{mg} / \mathrm{dL}$ set for women had been said to be too low for them [15]. Some of the HDL-C levels in the current report were higher than the average level $(54.0 \pm 9.4 \mathrm{mg} / \mathrm{dL})$ reported by Sowunmi et al. [12]. The LDL-C in our subjects was not desirable in any subject because no value was < $130 \mathrm{mg} / \mathrm{dL}$; in the borderline high of $130-159 \mathrm{mg} / \mathrm{dL}$ we had three subjects or $30 \%$ whilst seven subjects $(70 \%)$ were in high risk of $\geq 160 \mathrm{mg} / \mathrm{dL}$ LDL-C level. The blood cholesterol linked to atherosclerosis risk is LDL-C. HDL also carries cholesterol, but raised HDL represent cholesterol returning from the arteries to the liver and thus indicates a reduced risk of atherosclerosis and heart attack. It has been confirmed that high blood cholesterol carried in LDL correlates directly with heart disease, whereas high blood cholesterol in HDL correlates inversely with risk [7]. A significant difference existed among the LDL-C values. Our TG levels were all within the desirable level of $<200 \mathrm{mg} / \mathrm{dL}(58.6-100 ; 86.7 \pm 7.9 \mathrm{mg} / \mathrm{dL})$; our mean value was close to Sowunmi et al. [12] with a mean value of $89 \mathrm{mg} / \mathrm{dL}$. High TG alone normally does not indicate direct risk, but may reflect lipoprotein abnormalities associated with CHD. The risk of CHD increases as triglyceride levels increase in people with other risk factors. High TG also occurs in conditions such as kidney disease and diabetes, which suggest a high risk [7]. The VLDL-C has good relationship with the TG.

Bull. Chem. Soc. Ethiop. 2011, 25(1) 
The TC/HDL-C in Table 2 was greater than 4.5 (indicating risk for women) in five subjects $(50 \%)$. This ratio has been found to be highly predictive of heart disease risk, more so than total blood cholesterol alone [5]. Also the LDL-C/HDL-C ranges of 1.75-5.61 were above the American standard value of 3.4 in 5/10(50\%) of the subjects. Individuals with a LDL-C/HDL-C of 1.0 or TC/HDL-C of 3.4 are said to have about one half the heart disease risk of the average American [3]. The values of LDL-C/HDL-C were mostly higher than $2.02 \pm 0.8$ as reported by Sowunmi et al. [12].

Table 2. Ratio of values of TC/HDL-C and LDL-C/HDL-C in some Nigerian female serum samples (11-20 years age group), $\mathrm{n}=10$.

\begin{tabular}{|l|l|l|l|}
\hline Statistics & Age & TC/HDL-C & LDL-C/HDL-C \\
\hline \multirow{5}{*}{} & 18 & 5.75 & 4.28 \\
\cline { 2 - 4 } & 18 & 7.19 & 5.50 \\
\cline { 2 - 4 } & 18 & 3.00 & 1.75 \\
\cline { 2 - 4 } & 19 & 4.22 & 2.92 \\
\cline { 2 - 4 } & 19 & 3.81 & 2.58 \\
\cline { 2 - 4 } & 20 & 4.17 & 2.86 \\
\cline { 2 - 4 } & 20 & 7.17 & 5.61 \\
\cline { 2 - 4 } & 20 & 5.02 & 3.62 \\
\cline { 2 - 4 } & 20 & 4.87 & 3.55 \\
\cline { 2 - 4 } & 20 & 4.23 & 2.93 \\
\hline Mean & 19 & 4.94 & 3.56 \\
\hline SD & 0.92 & 1.4 & 1.3 \\
\hline CV\% & 4.8 & 28 & 35 \\
\hline
\end{tabular}

Table 3 contains the serum lipids in the ages 21-30 years range. The TC of this age range appeared to be relatively lower in most cases than in the 11-20 years age range although we had a minimum value of $197 \mathrm{mg} / \mathrm{dL}$ lower than in 11-20 years range $(200 \mathrm{mg} / \mathrm{dL})$ and a maximum value of $314 \mathrm{mg} / \mathrm{dL}$ higher than the highest level of $253 \mathrm{mg} / \mathrm{dL}$ in the 11-20 years age range. Only one subject had a desirable level of $<200 \mathrm{mg} / \mathrm{dL}$ among the subjects; 31 subjects or $86.1 \%$ population were in borderline high of $200-239 \mathrm{mg} / \mathrm{dL}$ and four or $11.1 \%$ subjects were in the high risk of $\geq 240 \mathrm{mg} / \mathrm{dL}$ TC. Akinkugbe [14] reported TC values of $117 \mathrm{mg} / \mathrm{dL}$ and 120 $\mathrm{mg} / \mathrm{dL}$ for hypertensive subjects and $244 \mathrm{mg} / \mathrm{dl}$ and $137 \mathrm{mg} / \mathrm{dL}$ for non-hypertensive subjects respectively with respective age of 22 years and 26 years female subjects. In the USA, the normal serum cholesterol in female subject of $20-24$ years was $170 \pm 3 \mathrm{mg} / \mathrm{dL}$ [16]; this value was much lower than most of the present results. Our TC values in Table 3 were close with a low level of CV of $10 \%$. In the HDL-C levels in Table 3, six subjects would be at risk with HDL-C levels $\leq 35 \mathrm{mg} / \mathrm{dL}$; this is about $16.7 \%$ of the population of subjects. For female subjects of age range 20-24 years in the USA, the normal HDL-C level was $53.0 \pm 1.0 \mathrm{mg} / \mathrm{dL}$. In our subjects, 30 or $83.3 \%$ of the population had HDL-C level above the critical level of 35 $\mathrm{mg} / \mathrm{dL}$. The values of HDL-C were more scattered than the value of TC as shown by their CV \% (Table 3). LDL-C levels in Table 3 showed that only one value was within the desirable level of $<130 \mathrm{mg} / \mathrm{dL}$ [4]; the range was between $125-202 \mathrm{mg} / \mathrm{dL}$ with a mean of $161 \pm 14 \mathrm{mg} / \mathrm{dL}$ although with low level of CV \% (8.7). The female normal LDL-C level of age range of 20-24 years in the USA was $104 \pm 2 \mathrm{mg} / \mathrm{dL}$ [16] which was much lower than our present report. In general, the higher the cholesterol (or, more specifically, the higher the LDL-C) the greater the risk of CHD. Research suggests that men with high cholesterol levels when they are young (mean age of 22 years) have a high risk of developing heart disease later in life [7]. Almost half of all deaths from CHD occur among men with blood cholesterol in the borderline- high range [17]. In the age range of 20-24 years, the normal VLDL-C level is $13.5 \pm 0.6 \mathrm{mg} / \mathrm{dL}$ in the USA 
[16]; only two subjects or $5.56 \%$ of our subjects were in this category with values of $10.8-11.7$ $\mathrm{mg} / \mathrm{dL}$ in the age range of 28-29 years. The TG in Table 3 was all within the desirable level of < $200 \mathrm{mg} / \mathrm{dL}$ [4] as also found in Table 1 . The TG had a CV \% of 12 showing the values were more homogenous than being heterogeneous. In Table 3 both TC and HDL-C had F-calculated $>$ F-table in their columns, meaning that each parameter was significantly different within its column.

Table 3. Lipids (mg/dL) in some Nigerian female serum samples (21-30 years age group), $\mathrm{n}=36$.

\begin{tabular}{|c|c|c|c|c|c|c|}
\hline Statistics & Age & $\mathrm{TC}^{*}$ & HDL-C & LDL-C & VLDL-C & TG \\
\hline & 21 & 244 & 65.5 & 162 & 16.4 & 82 \\
\hline & 21 & 218 & 53.4 & 147 & 18.0 & 89.9 \\
\hline & 21 & 212 & 32.1 & 162 & 17.8 & 88.8 \\
\hline & 22 & 218 & 38.3 & 163 & 16.4 & 82 \\
\hline & 22 & 233 & 40.4 & 176 & 16.2 & 81.2 \\
\hline & 22 & 214 & 36.6 & 161 & 16.5 & 82.4 \\
\hline & 22 & 208 & 35.5 & 156 & 16.0 & 80.1 \\
\hline & 22 & 218 & 74.5 & 125 & 18.7 & 93.4 \\
\hline & 23 & 283 & $>70$ & 197 & 16.5 & 82.4 \\
\hline & 23 & 197 & 28.5 & 146 & 22.2 & 111 \\
\hline & 23 & 212 & 40.0 & 155 & 17.1 & 85.4 \\
\hline & 23 & 218 & 41.4 & 158 & 18.6 & 93.1 \\
\hline & 23 & 314 & $>90$ & 202 & 22.3 & 111 \\
\hline & 24 & 218 & 35.1 & 169 & 14.2 & 70.9 \\
\hline & 24 & 238 & 62.1 & 158 & 17.5 & 89.7 \\
\hline & 24 & 263 & 64.7 & 179 & 19.4 & 97.2 \\
\hline & 24 & 214 & 37.4 & 157 & 18.0 & 90 \\
\hline & 24 & 210 & 36.6 & 156 & 17.0 & 85.1 \\
\hline & 24 & 218 & 40.1 & 161 & 17.0 & 85.2 \\
\hline & 24 & 232 & 45.5 & 168 & 17.48 & 87.4 \\
\hline & 25 & 223 & 42.1 & 165 & 16.0 & 80.1 \\
\hline & 25 & 201 & 28.5 & 154 & 18.7 & 93.6 \\
\hline & 25 & 204 & 33.1 & 153 & 18.1 & 90.4 \\
\hline & 25 & 224 & 52.2 & 155 & 17.0 & 85.1 \\
\hline & 25 & 206 & 46.6 & 142 & 17.3 & 86.3 \\
\hline & 25 & 231 & 63.4 & 148 & 19.3 & 96.4 \\
\hline & 25 & 228 & 36.4 & 174 & 17.5 & 89.4 \\
\hline & 26 & 223 & 45.4 & 160 & 17.7 & 88.7 \\
\hline & 26 & 213 & 33.1 & 162 & 18.1 & 90.3 \\
\hline & 26 & 226 & 53.4 & 154 & 18.5 & 92.2 \\
\hline & 27 & 231 & 47.4 & 166 & 17.1 & 85.7 \\
\hline & 27 & 211 & 39.4 & 154 & 17.6 & 88.1 \\
\hline & 28 & 231 & 57.8 & 161 & 11.7 & 58.6 \\
\hline & 29 & 221 & 35.8 & 174 & 10.8 & 54 \\
\hline & 29 & 204 & 31.1 & 156 & 16.7 & 83.4 \\
\hline & 29 & 205 & 37.6 & 148 & 19.1 & 95.4 \\
\hline Mean & 24.4 & 224 & 45.9 & 161 & 17.4 & 86.8 \\
\hline SD & 2.2 & 23 & 14 & 14 & 2.2 & 11 \\
\hline $\mathrm{CV} \%$ & 9.2 & 10 & 31 & 8.7 & 12 & 12 \\
\hline
\end{tabular}

* Results significantly different within members of each column.

The TC-to-HDL-C had value of 2.93-7.05 (Table 4). All the values (except one, 2.93\%) were higher than the standard non-risk value of 3.4 indicating the risk of CHD. In the case of 
LDL-C/HDL-C, 27 (75\%) of the population had LDL-C/HDL-C less than the risk value of 4.5 [4] whereas the rest would be highly susceptible to CHD.

Table 4. Ratio of values of TC/HDL-C and LDL-C in some Nigerian female serum samples (21-30 years age group), $\mathrm{n}=36$.

\begin{tabular}{|c|c|c|c|}
\hline Statistics & Age & TC/HDL-C & LDL-C/HDL-C \\
\hline & 21 & 3.73 & 2.47 \\
\hline & 21 & 4.08 & 2.75 \\
\hline & 21 & 6.60 & 5.05 \\
\hline & 22 & 5.69 & 4.26 \\
\hline & 22 & 5.77 & 4.37 \\
\hline & 22 & 5.85 & 4.40 \\
\hline & 22 & 5.86 & 4.41 \\
\hline & 22 & 2.93 & 1.68 \\
\hline & 23 & 4.04 & 2.81 \\
\hline & 23 & 6.91 & 5.13 \\
\hline & 23 & 5.30 & 3.87 \\
\hline & 23 & 5.27 & 3.82 \\
\hline & 23 & 3.49 & 2.24 \\
\hline & 24 & 6.21 & 4.81 \\
\hline & 24 & 3.83 & 2.55 \\
\hline & 24 & 4.06 & 2.76 \\
\hline & 24 & 5.72 & 4.24 \\
\hline & 24 & 5.74 & 4.27 \\
\hline & 24 & 5.44 & 4.01 \\
\hline & 24 & 5.10 & 3.69 \\
\hline & 25 & 5.30 & 3.92 \\
\hline & 25 & 7.05 & 5.40 \\
\hline & 25 & 6.16 & 4.62 \\
\hline & 25 & 4.29 & 2.97 \\
\hline & 25 & 4.42 & 3.06 \\
\hline & 25 & 3.64 & 2.34 \\
\hline & 25 & 6.26 & 4.78 \\
\hline & 26 & 4.91 & 3.52 \\
\hline & 26 & 6.44 & 4.89 \\
\hline & 26 & 4.23 & 2.89 \\
\hline & 27 & 4.87 & 3.51 \\
\hline & 27 & 5.36 & 3.91 \\
\hline & 28 & 4.00 & 2.79 \\
\hline & 29 & 6.17 & 4.87 \\
\hline & 29 & 6.56 & 5.02 \\
\hline & 29 & 5.45 & 3.94 \\
\hline Mean & 24.4 & 5.19 & 3.78 \\
\hline SD & 2.2 & 1.1 & 0.97 \\
\hline $\mathrm{CV} \%$ & 9.2 & 21 & 26 \\
\hline
\end{tabular}

Table 5 shows the TC, HDL-C, LDL-C, LDL-C, VLDL-C and TG for age group 31-40 years. The TC here had the same pattern of concentration as observed in the TC of Table 1 (1120 years age group). The CV \% was however larger than in Table 1 TC CV \%. Akinkugbe [14] reported TC value of $151 \mathrm{mg} / \mathrm{dL}$ (hypertensive) and 137 for non-hypertensive 32 years old female subjects. These values were even lower than the present report. The normal average TC in an American woman of age 40-44 years had been reported as 197.5 $\pm 1.9 \mathrm{mg} / \mathrm{dL}$ which was 
lower than our present report. All our TC results were all outside the desirable level of $<200$ $\mathrm{mg} / \mathrm{dL}$ and some were still outside the borderline level of $200-239 \mathrm{mg} / \mathrm{dL}$ [4] making the subjects susceptible to CHD. The HDL-C levels of $23.4-68.4 \mathrm{mg} / \mathrm{dL}$ had one value $(25 \%)$ less than the risk level of $\leq 35 \mathrm{mg} / \mathrm{dL}$ whereas three subjects or $75 \%$ were outside the risk level. The normal HDL-C in the American woman of age group 40-44 years had been put at 57.8 \pm 0.9 (16), only one result in HDL-C (Table 5) was better than the reference report. The LDL-C levels were all higher than the desirable level of $<130 \mathrm{mg} / \mathrm{dL}$ [4], whereas one result was in the borderline high of $130-159 \mathrm{mg} / \mathrm{dL}$ and three in high risk level of $\geq 160 \mathrm{mg} / \mathrm{dL}$ [4]. The LDL-C in the American woman of age group 40-44 years was $125 \pm 2$ [16] which was lower than all our LDLC levels. The VLDL-C in Table 5 was $16.2-19.4 \mathrm{mg} / \mathrm{dL}$ which was higher $14.7 \pm 0.5 \mathrm{mg} / \mathrm{dL}$ in the American woman of age bracket 40-44 years [16]. The TG in Table 5 like the previous results was all lower than $200 \mathrm{mg} / \mathrm{dL}$ which meant they were all within the desirable level. Most studies examining heart disease involve only men [7]. The significance of findings on LDL and HDL to women is less clear. Women younger than 45 years tend to have lower concentrations of LDL-C than men of the same age, but women's blood cholesterol begin to exceed those of men between the age of 45 and 55. After age 55, the disparity in LDL-C becomes even greater. The F-test results for TC showed that F-calculated $>$ F-table at $\alpha=0.05$, hence, results were significantly different in the column. The TC/HDL-C in Table 6 had all its values greater than 3.4 which meant that the subjects would be susceptible to CHD whereas subject with LDLC/HDL-C value of 6.89 would have the problem of CHD but the others had LDL-C/ HDL-C level less than 4.5.

Table 5. Lipids (mg/dL) in some Nigerian female serum samples (31-40 years age group), $\mathrm{n}=4$.

\begin{tabular}{|l|l|l|l|l|l|l|}
\hline Statistics & Age & TC $^{*}$ & HDL-C & LDL-C & VLDL-C & TG \\
\hline \multirow{5}{*}{} & 32 & 202 & 35.5 & 147 & 19.4 & 97.1 \\
\cline { 2 - 7 } & 35 & 256 & 68.4 & 170 & 17.8 & 88.8 \\
\cline { 2 - 7 } & 37 & 243 & 48.7 & 178 & 16.2 & 81.1 \\
\cline { 2 - 7 } & 39 & 203 & 23.4 & 161 & 18.7 & 93.4 \\
\hline Mean & 36 & 226 & 44 & 164 & 18.0 & 90.1 \\
\hline SD & 3.0 & 28 & 19 & 13 & 1.4 & 6.9 \\
\hline CV\% & 8.3 & 12 & 44 & 8.1 & 7.7 & 7.7 \\
\hline
\end{tabular}

*Results significantly different among member of the column.

Table 6. Ratio of values of TC/HDL-C and LDL-C/HDL-C in some Nigerian female serum samples (31-40 years age group), $\mathrm{n}=4$.

\begin{tabular}{|l|l|l|l|}
\hline Statistics & Age & TC/HDL-C & LDL-C/HDL-C \\
\hline \multirow{5}{*}{} & 32 & 5.69 & 4.14 \\
\cline { 2 - 4 } & 35 & 3.74 & 2.48 \\
\cline { 2 - 4 } & 37 & 4.99 & 3.66 \\
\cline { 2 - 4 } & 39 & 8.68 & 6.88 \\
\hline Mean & 36 & 5.78 & 4.29 \\
\hline SD & 3.0 & 2.1 & 1.9 \\
\hline CV\% & 8.3 & 36 & 43 \\
\hline
\end{tabular}

In Table 7 (41-50 years, one subject), (51-60 years, and one subject) and (71-80 years, one subject) had respective values of: TC, HDL-C, LDL-C, VLDL-C and TG as shown in Table 7. It was observed that it appeared that the TC and the LDL-C were on the high side compared with previous age group, whilst the TG followed the earlier patterns. All the three subjects had TC between 233-251 mg/dL which could lead to CHD; all the HDL-C values were higher than 35 
$\mathrm{mg} / \mathrm{dL}$ which suggested non-risk of CHD; LDL-C ranged from 135-173 mg/dL with the range of risk of borderline high (130-159 mg/dL) and high risk of CHD with a value of $d \geq 160 \mathrm{mg} / \mathrm{dL}$. All the TG values were all less than $200 \mathrm{mg} / \mathrm{dL}$ which is the desirable level. The TC/HDL-C and LDL-C/HDL-C for the age 41-80 tears are in Table 8. For the obtained results were: TC/HDLC, LDL-C/HDL-C (2.87, 1.67); (4.16, 2.87); (3.95, 2.64). Two of the TC/HDL-C levels were greater than 3.4 [5], susceptibility to CHD would likely be high; however, all the LDL-C/HDL$\mathrm{C}$ levels were all lower 4.5 which is the risk level [4]. In the American woman of age group of 50-54 years: normal TC $(217 \pm 2 \mathrm{mg} / \mathrm{dL})$, normal HDL-C $(62.0 \pm 1.0 \mathrm{mg} / \mathrm{dL})$, normal VLDL-C $(17.2 \pm 0.7 \mathrm{mg} / \mathrm{dL})$ and LDL-C $(138 \pm 2 \mathrm{mg} / \mathrm{dL})[16]$; these literature values of TC, HDL-C, VLDL-C and LDL-C results were better than some of our results in the age bracket of 40-80 years. At menopause, LDL tends to rise and HDL decline. This appears to agree with our present report. About one third of the women in the USA have LDL-C high enough to pose a serious risk of heart disease [18]. Table 9(a) and 9(b) give summaries of the range values with the range differences in brackets. Only ages 11-20, 21-30, 31-40 years had enough information for range calculation exercises.

Table 7. Lipids ( $\mathrm{mg} / \mathrm{dL})$ in some Nigerian female serum samples of other age groups.

\begin{tabular}{|c|c|c|c|c|c|c|c|c|}
\hline S.No. & No. & Age group & Age & TC & HDL-C & LDL-C & VLDL-C & TG \\
\hline 1 & 1 & $41-50$ & 42 & 233 & 81.1 & 135 & 16.8 & 85.8 \\
\hline 2 & 1 & $51-60$ & 52 & 251 & 60.3 & 173 & 17.6 & 88 \\
\hline 3 & - & $61-70$ & - & - & - & - & - & - \\
\hline 4 & 1 & $71-80$ & 72 & 238 & 60.3 & 159 & 18.8 & 94 \\
\hline
\end{tabular}

Table 8. Ratio values of TC/HDL-C and LDL-C/HDL-C in some Nigerian female serum samples of other age groups.

\begin{tabular}{|c|c|c|c|c|c|}
\hline S/N & No. & Age group & Age & TC/ HDL-C & LDL-C/HDL-C \\
\hline 1. & 1 & $41-50$ & 42 & 2.87 & 1.67 \\
\hline 2. & 1 & $51-60$ & 52 & 4.16 & 2.87 \\
\hline 3. & - & $61-70$ & - & - & - \\
\hline 4. & 1 & $71-80$ & 72 & 3.95 & 2.64 \\
\hline
\end{tabular}

Table 9(a). Range of variation of some parameters for the different age groups in their serum samples.

\begin{tabular}{|c|c|c|c|c|l|}
\hline Age group & Age & TC & HDL-C & TC/HDL-C & LDL-C/HDL-C \\
\hline $11-20$ & $18-20(2)$ & $200-244(44)$ & $27.8-80.1(52)$ & $3.00-7.19(4.19)$ & $1.75-5.61(3.86)$ \\
\hline $21-30$ & $21-29(8)$ & $197-314(117)$ & $28.5-90(61)$ & $2.93-7.05(4.12)$ & $1.68-5.40(3.72)$ \\
\hline $31-40$ & $32-39(7)$ & $202-256(54)$ & $23.4-68.4(45)$ & $3.74-8.68(4.94)$ & $2.48-6.88(4.4)$ \\
\hline
\end{tabular}

Table 9(b). Range of variation of some parameters for the different age groups in their serum samples.

\begin{tabular}{|c|c|c|c|c|}
\hline Age group & Age & LDL-C & VLDL-C & TG \\
\hline $11-20$ & $18-20(2)$ & $140-171(31)$ & $15.1-20.0(4.9)$ & $58.6-100(41)$ \\
\hline $21-30$ & $21-29(8)$ & $125-202(77)$ & $10.8-19.3(8.5)$ & $54-111(57)$ \\
\hline $31-40$ & $32-39(7)$ & $147-178(31)$ & $16.2-19.4(3.2)$ & $81.1-97.1(16)$ \\
\hline
\end{tabular}

In summary, this report showed that significantly different results existed in LDL-C (Group I, 11-20 years); TC and HDL-C (Group II, 20-30 years); TC (Group III, 30-40 years). The TG levels in all the subjects were in desirable level of $<200 \mathrm{mg} / \mathrm{dL}$; only one subject (1.89\%) (age, 21-30 years) had TC value of $<200 \mathrm{mg} / \mathrm{dL}$; for HDL-C, nine subjects $(17.0 \%)$ had HDL-C $\leq 35$ $\mathrm{mg} / \mathrm{dL}$; in LDL-C only one subject (1.89\%, age, $21-30$ years) had a desirable level of LDL-C < $130 \mathrm{mg} / \mathrm{dL}$. In TC/HDL-C, only three subjects (5.66\%, age, 11-50 years) had values less than 
3.4 and in LDL-C/HDL-C, 41 subjects ( $77.4 \%$; cutting across the age groups) had values $<4.5$. Hence, TC, HDL-C, LDL-C, TC/HDL-C and to a lesser extend LDL-C/HDL-C could contribute to increased risk of ateriosclerotic heart disease and familial hyperlipoproteinemia. Most of the present results were higher than the American reference examples on similar age ranges.

\section{ACKNOWLEDGEMENTS}

The authors appreciate the technical assistance of Mr. A.A. Peters of the Nigeria National Petroleum Corporation (NNPC) Medical Laboratory, Warri, Delta State, Nigeria.

\section{REFERENCES}

1. Livingstone, C. Pocket Medical Dictionary, 14th ed., Association with the Royal Society of Medicine: London; 1999.

2. Adeyeye, E.I.; Iyoha, A.A.; Ogunlade, I. Biosci. Biotech. Res. Asia 2006, 3, 63.

3. Nieman, D.C.; Butterworth, D.E.; Nieman, C.N. Nutrition. Wm C Brown Publishers: Dubuque; 1991; pp 495-497.

4. Expert Panel on Detection, Evaluation and Treatment of High Blood Cholesterol in Adults (Adults Treatment Panel II) J. Am. Med. Assoc. 1993, 269, 3015.

5. American Health Foundation Plasma Lipids: Optimal Levels for Health, Academic Press: New York; 1980; in: Nutrition, Nieman, D.C.; Butterworth, D.E.; Nieman. C.N. (Eds.), Wm C Brown Publishers: Dubuque; 1991; p 138.

6. Simons, L.A.; Gibson, J.C.; Plasma Lipids and Lipoproteins in Nutrition, Nieman, D.C.; Butterworth, D.E.; Nieman, C.N.; Wm C Brown Publishers: Dubuque, 1991; p 137.

7. Whitney, E.N.; Cataldo, C.B.; Rolfes, S.R. Understanding Normal Clinical Nutrition, $4^{\text {th }}$ edition, West Publishing Company: New York; 1994; Medicine pp 132-168.

8. Eastham, R.D. Biochemical Values in Clinical Medicine, 7th ed., John Wright and Sons: Bristol, 1985; pp 90-91.

9. Berg, J.M.; Tymoczko, J.L.; Stryer, L. Biochemistry, 5th ed., WH Freeman: New York; 2002; pp 974-976.

10. Wardlaw, G.M. Contemporary Nutrition: Issues and Insights, 5th ed., McGraw-Hill Education: Boston; 2003; pp 143-186.

11. Oloyo, R.A. Fundamentals of Research Methodology for Social and Applied Sciences, ROA Educational Press: Ilaro, Nigeria; 2001; pp 53-200.

12. Sowunmi, A.; Walker, O.; Salako, L.A. Afr. J. Med. Sci. 1996, 25, 213.

13. Edozien, J.C. West Afr. Med. J. 1978, 1, 121.

14. Akinkugbe, O.O. High Blood Pressure in the African, Churchill Livingstone: London; 1972; p 96.

15. National Institutes of Health J. Am. Med. Assoc. 1993, 269, 505.

16. The Lipid Research Clinical Population Statistics Data Book, Volume 1. The Prevalence Study. US Department of Health and Human Sciences. National Institutes of Health, Washington, USA, 1980. in: Biochemical Values in Clinical Medicine, Eastham, R.D. (Ed.), 7th ed., John Wright and Ltd: Bristol; 1985; p 90.

17. Canadian Consensus Conference on Cholesterol: Final Report (Ottawa: The Government Conference Center, 1988), in: Understanding Normal Clinical Nutrition, Whitney, E.N.; Cataldo, C.B.; Rolfes, S.R. (Eds.), 4th ed., West Publishing Company: New York; 1994; p 880 .

18. National Institutes of Health: National Heart, Lung, and Blood Institute The Healthy Heart Handbook for Women, NIH Publication No. 92- 2720; in: Understanding Normal Clinical Nutrition, Whitney, E.N.; Cataldo, C.B.; Rolfes, S.R. (Eds.), 4th ed., West Publishing Company: New York; 1994; p 884. 